\section{Peer review}

SIR - The problems of peer review procedures deserve serious consideration, but the remedy proposed by M.C. Goodall (Nature, 23 August, p. 620), an effective appeal process, is not practicable. Grants committees have little difficulty in identifying outstanding or mediocre proposals; it is the predominant mass of attractive sound applications that cause the problems. In the "good old days", virtually all of these would have been supported. Today a large proportion fail, their fates being determined by slight variations in the (usually secret) scoring by various members of the committee. Mean scores determine a rank order which is the basis for allocating funding from the top of the order until the funds are exhausted.

It would be quite iniquitous to review at appeal a single application that had failed without also reviewing all the competing (even successful) applications, perhaps even including those that were successful. Who is to say that a second complete review would be any more just than the initial review? In a situation of diminished resources it has to be accepted (albeit reluctantly) that a considerable element of chance is an inescapable component of today's review procedures.

The only marginal improvement that might be worth considering would be a more sensitive scoring system in the critical region around the anticipated cut-off point. For example, at present one major grant award-body scores from 0 (bad) to 6 (outstanding) with a funding cut-off in the region of 3.7. In practice most good applications are scored either 3 or 4 by committee members and the mean score can be moved from one side of the cut-off point to the other by just one member altering a score from 3 to 4 , or vice versa. If members could score in fractions in this region rather than integers they could exercise greater discrimination, giving a somewhat less chancy mean score.

BRYN BRIDGES

MRC Cell Mutation Unit

University of Sussex,

Brighton BNI 9RR, UK

\section{Nature bingo?}

SIR - It occurs to me that the current "Bingo War" in Fleet Street may pose a serious threat to the maintenance of Nature's circulation. May I therefore suggest a way in which this might be countered? I propose the institution of a new game entitled "Base Sequence". Each subscriber would be sent his own "DNA card" on which would be printed a unique sequence of 36 bases. Three or four tRNA anticodons would then be printed in each issue of Nature (possibly at the bottom of the contents page), the winner being the first reader to match up his base sequence with a complete set of complementary triplets, thus completing his peptide. Obviously frame-shifts and "spare" bases could not be allowed!

I feel certain that such a course of action would assure the future of the journal, the only possible disadvantage being the risk of attracting the eye of Rupert Murdoch or Robert Maxwell.

S.J. Publicover 293 Heeley Road,

\section{Selly Oak,}

Birmingham B29 6EL, UK

\section{Brazilian science}

SIR: - Your special offer for Brazilian scientists to purchase Nature is important not only in helping Brazilian scientists to keep themselves up to date in science, but also in calling attention to the isolation from the international scientific community of Brazilian scientists due to the present policy of budgetary restrictions for science and education. The faculty members of the Brazilian federal universities are involved in a national struggle for better working and teaching conditions. Among other facilities that are becoming inoperable, the libraries are at the moment incapable of renewing their subscriptions due to lack of money for education in addition to the restrictions on foreign exchange.

MARCELLO ANDRÉ BARCINSKI Departamento de Biofísica Celular, Instituto de Biofísica,

Universidade Federal do Rio de Janeiro, 21941 Rio de Janeiro, Brazil

\section{Bio company launch}

SIR - Since Nature has a long standing interest in promoting advances in biotechnology, we have chosen to make the first announcement of our new venture in your pages.

At a recent meeting of the American Society of Biological Chemists (ASBC, San Francisco, June 1983), we were amazed by the number of biochemists who are owners, co-owners or owned (as "consultants") by private enterprises. Our unbiased survey of participants at this meeting revealed the following (see figure).

At the time of Adam and Eve, less than 0.001 per cent of all living scientists were engaged in profit-yielding activities. Much later (see small blip in curve) a sizeable percentage of scientists convinced the public that lead could be transformed into gold. In the 1980s, this logic has been extremely successful ${ }^{1,2}$. There are a number of explanations for the rapid increase shown in the figure other than blatant greed including (1) new techniques for producing monoclonal antibodies; (2) gene cloning; (3) gullibility of the public.

At the San Francisco ASBC meeting, we were quite embarrassed not to have an official company business card, as did all our friends. Furthermore, when walking back to our sleazy hotel (Taylor Street, et $a l$.) late one night, we were approached by two charming women asking "would you like a little company?" This encounter sparked our interest and we decided to start our own enterprise.

As indicated on our tastefully designed letterhead, Genasex was conceived. The response has been fantastic. In our travels, many scientists have expressed keen interest and overt jealousy. Suggestions

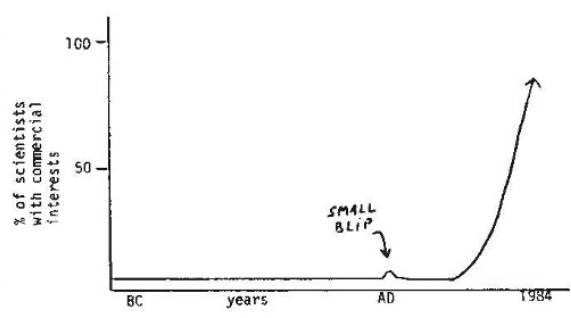

arrive daily. One colleague advised changing our name from Genasex Ltd to Genasex Unlimited. A colleague from Milan offered to head an Italian subsidiary to be called Gen-italia, but we have postponed a decision on that.

What products does our company produce? So far, none. The reasons for this policy include (1) our observation that many of the new biotechnological companies also produce no products; (2) of those who do, most are in the red; and (3) to use this company as an effective tax writeoff, we must be careful not to be too successful.

Hitherto, our financial investment has been negligible. Naturally, we solicit readers' contributions and would certainly consider adding names to our board of directors. Our real hope is that another company, perhaps with a similar name, would offer to buy us in order to avoid the inevitable competition. D. MALAMUD

J. HANOUNE

Genasex Ltd, c/o University of Pennsylvania,

Thomas W. Evans Museum

\& Dental Institute,

4001 Spruce Street,

Philadelphia, Pennsylvania 19104, USA

1. Dow-Jones et al., any day, any paper.

2. Nature, Index of Biotechnology Stocks, monthly reports.

\section{Photocopying}

SIR - J.D. St Aubyn (Nature 304, 678; 1983) correctly stresses that it is publishers and not authors who are concerned about large-scale copying. In fact most reputable suppliers of tear sheets or photocopies, ourselves included, adhere to the requirements of the Copyright Clearance Center (CCC), so eliminating most of the administative copying.

The price of an authorized photocopy includes the CCC payment, I believe the British Lending Library has agreed to pay CCC fees on all photocopies mailed to the United States.

EUGENE GARFIELD

Institute for Scientific Information,

University City Science Center, Philadelphia, Pennsylvania 19104, USA 